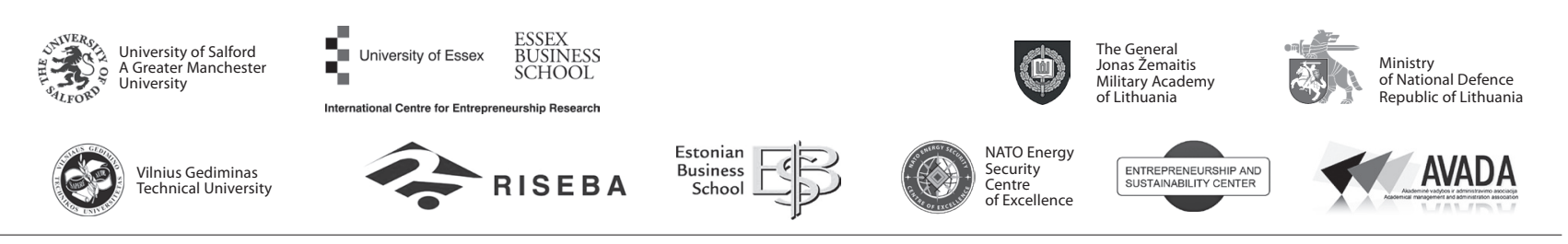

\author{
JOURNAL OF SECURITY AND SUSTAINABILITY ISSUES \\ ISSN 2029-7017 print/ISSN 2029-7025 online \\ 2017 December Volume 7 Number 2 \\ https://doi.org/10.9770/jssi.2017.7.2(7)
}

\title{
IDENTIFICATION OF THE COMPLEX TAX SYSTEM EVALUATION CRITERIA: THEORETICAL ASPECT
}

\author{
Gintarè Giriūnienė¹, Lukas Giriūnas² \\ ${ }^{1,2}$ Mykolas Romeris University, Ateities str. 20, Vilnius, Lithuania \\ E-mails: 'gintare.giriuniene@mruni.eu; ${ }^{2 l u k a s . g i r i u n a s @ m r u n i . e u ~}$
}

Received 20 February 2017; accepted 26 September 2017

\begin{abstract}
Recently, the countries try to attract more foreign investments, improve the standard of living in the country and improve not only macroeconomic but also the indicators of the personal life satisfaction. More and more attention is paid to the tax system reorganization and evaluation. However, the different evaluation methods of the tax system can give different results and for this reason, there is not so simple to choose the right method or complex. The research was done with purpose to find out, which method of the evaluation of the tax system would be the most acceptable. On the basis of the results of the empirical study, there were identified the complex tax system evaluation criteria. According to them, the country, taking into account its specific characteristics, can compose the suitable complex tax system evaluation model. It can help to evaluate the country's tax system in the most objectively way.
\end{abstract}

Keywords: evaluation of the tax system, principles of the taxation, the methodology of the evaluation

Reference to this paper should be made as follows: Giriūnienė, G.; Giriūnas, L. 2017. Identification of the complex tax system evaluation criteria: theoretical aspect, Journal of Security and Sustainability Issues 7(2): 257-265. https://doi.org/10.9770/ jssi.2017.7.2(7)

JEL Classifications: H20, H71

\section{Introduction}

It can be stated that the evaluation of the tax system is the most important condition of the constructive tax system and the targeted management. However, we should keep in mind that each country has their particularities. The generation of tax revenue volumes and the purpose belong from these particularities. Despite the fact that each country's tax system is formed according to the foreseen priorities, economic-social programs, percularities, but the tax systems are currently being evaluated by the different scientist's proposed methods. So it is very difficult to evaluate their development policies and other issues. For this reason, the country's tax system assessment is not so simple. Also, the united tax system evaluation model is not prepared and the various scientists and experts of the market evaluate the tax system using the different methods or simply provide just intuitive evaluation, which is not based on the empirical research. For this reason, it is not clear how and in what direction the country's tax system can be improved. When the countries, which are less advanced economically, try to improve the tax system, they usually suffer fiasco. The methodological insufficiency and the increasing volumes of the tax system improvement in the different countries have led to the choice of research direction. The analysis of the various scientific literature shows that the scientists and the experts of the market assess it very differently, although the type of fees, taxpayers, administrators, the order of the payment and the declaration are clearly defined in the existing tax law. However, the evaluation and its problem is poorly explored in both theoretical and methodical point of view. According to Jakstonyte and Giriunas (2010), such a research, which is not based on any empirical studies 
within a few years, loses not only the residual value but also the significance. It belongs from the ever-changing economic situation in the country and because of the drastic reconstruction in the tax system of the country. It is not so easy to identify and evaluate the evaluation criteria of the dynamic tax system using the clearly measurable parameters. The reason is that every country has developed a unique and the most suitable tax system. There are a lot of scientists who analyze the tax systems, e.g. Tanzi (1977, 1983, 2001, 2005), Skačkauskienè (2008, 2009, 2010, 2011), Slemrod (2001, 2005, 2012 2013), Gill (2000) and other foreign scientists. They analyze the evaluation methods of the tax system. However, when the analysis of this literature was done, it turned out that there is paid insufficient attention to the research of the complex tax system evaluation technique or method. This method is adapted to the countries according to the specific criteria. It should be noted that the presented research in the scientific literature is carried out according to the various tax system evaluation methods and techniques. There was carried out the comparative analysis of the different countries tax system. There was also foreseen the improvement directions of the tax rates, the taxation base, the taxation principles and other issues.

The subject of this study is the country's tax system.

The objective of the study is to identify and evaluate the complex tax system evaluation criteria. This work consists of the analysis of research, empirical studies and economic readings. Also, there was done a practice study related to the questions of the tax system evaluation methods.

\section{The critical review and analysis of literature}

The main function of the tax system is to generate the tax revenue of the country. However, the fees are often treated as the redistribution tool of the revenue, which is dedicated to correct the gaps of the market mechanism and redistribute the revenue (Gasparénienè et al.2016; Tamulevičiené 2016; Dobrovič et al. 2017; Sika et al. 2016). For this reason, scientists Skackauskiene (2009), Alley and Bentley (2008), Jakstonyte and Giriunas (2010), Profeta and Scabrosetti (2009), Tanzi (2004), Gill (2010) and others suggest several methods, which can help to evaluate the tax system. However, both scientists and experts of the market agree that there is not prepared the united tax system evaluation method, which can evaluate the country's tax system in various aspects. Perhaps it is not even expedient because not all the researchers of the tax system are interested in the same cross-section of the tax system and in the analytic aspects. However, it should be noted that in the scientific literature, can be distinguished the five most frequently occurring tax system methods and its administration evaluation methods. The five most frequently used methods are these: the productivity test of Tanzi, the diagnostic indicators analysis of Gill, the collection of the presentations of Tanzi and Pallechio, the tax burden rate and the classical principles of the taxation and their indicators. It should be noted that the most frequently used methods of the evaluation of the tax system do not have the evaluation aspect of the country specificity. Therefore, it can be said that environment of the scientific evaluation of the tax system requires a new research. It is needed due to the new tax system evaluation model. This model can assess the country's particularities. For this purpose, it is essential to carry out a detailed analysis of the following methods that the evaluation criteria list of the country tax system would be built as objectively as possible.

The scientist Tanzi (2004) is the representative of the International Monetary Fund. He codified the pre-existing tax system assessment methods and submitted a new one. In the new one, there was distinguished the eight qualifying and diagnostic evaluation indicators. Each indicator is evaluated by the specific question. The replies, which were received from the selected experts, can be positive, negative or satisfactory. According to the whole of the received responses, the country's tax system can be evaluated. However, such proposed tax system evaluation method must be regarded as a subjective opinion about the tax system of the country. It should be noted that the different experts evaluate the tax systems of the various countries. For this reason, there is an extremely high probability of discrepancies. The tax system evaluation method formed by Tanzi does not specify a specific rating scale, or at least the limits of the scale. It cannot be used for the international comparisons of the tax system. Atwood, Drake, Mayers and Myers (2012) state that, if the tax system evaluation method is not suitable for the international research, it becomes aimless because the evaluation of one country's tax system becomes meaningless. Despite the prevailing contradictory opinions, Tanzi method is used in practice for a sufficiently long period. 
The concentration index is indicated in the evaluation method of Tanzi. This index shows whether a sufficiently large part of the general tax revenue is collected from a relatively small number of taxes and tax rates. For example, in Lithuania, even about eighty percent of the national budget tax revenue is composed of the revenue from the five major taxes. However, the existing number of the taxes may not reflect the functionality of the tax system and even the efficiency of its. The reason is that the taxes can be collected optimally only from the several major taxes if their administration is effective and the tax legislation is thoroughly prepared, so then the tax system can function properly. The dispersion index of Tanzi shows whether there are any taxes from which are received especially low revenue, but they make a lot of trouble administering them. The relatively low-income taxes in Lithuania are not so much. However, comparing the tax systems in the international rate, it is quite difficult to determine the exact number of the relatively low-income taxes throughout the system. Precisely for this reason, it is quite difficult to evaluate the tax system according to this indicator (the higher dispersion index is, the less efficient is the tax system). The rate of the erosion is assessed very critically by the scientists Abdrerratar and Subhash (1997), Spratt (2009). This rate shows the proximity of the actual tax base to the potential tax base. For example, in Lithuania, the tax base is relatively wide, but there is no potential tax-free basis. Unless we can assign the tax incentives, which are provided in the relevant statutory or the tax losses, which are influenced by the volumes of the shadow economy. Many of the proposed indicators of Tanzi were assessed critically in the scientific literature. However there should be noted that some of them are clearly defined. For example, the delay indicator collecting the taxes shows whether the fees are paid on time, i.e. as defined by the tax laws. This information is not easily accessible, but at least it is objectively measured. Also, it is suitable for the international comparisons. Evaluating the tax system, according to Tanzi (1983), it is very important to assess how much the tax system depends on the taxes, whose rates are specific (the physical characteristics of the product - the quantity, weight or value). The tax system is evaluated positively if exist a relatively small number of the taxes because the more taxes are in the tax system, the more difficult is to administer them. According to Tanzi (2005), it means the inefficient tax system. It should be noted that in the scientific literature the tax system evaluation method of Tanzi is often encountered, but in practice, it is quite rarely used. This method is not normative and it indicates only the most important aspects which should be noted evaluating the country's tax system.

The next tax system evaluation method is very similar to Tanzi and it is suggested by the scientist Gill. It is the system of the diagnostic indicators, which is split into two parts - the quantitative and the qualitative aspects of the assessment of the tax system. According to Gill (2000), the tax system evaluation method helps to disclose the process gaps of the revenue administration. Also, it helps to disclose the positions, where the administration of the revenue does not match to the expectations of the taxpayers. The analysis of the tax revenue collection system provides a possibility to evaluate the efficiency of the total tax system. The tax system method proposed by Gill is quite positively evaluated by the scientists. When this method is applicable, the tax system can be analyzed systematically and through the prism of the tax revenue collection.

According to Bivainis and Skackauskiene (2009), analyzing the components of the tax system, there is revealed their impact on the system. The efficiency of the system depends on the harmony between the components. It should be noted that using this method for evaluation of the tax system, there is confronted with one crucial problem - the accessibility of data. This problem occurs because there is needed a very wide range collection of the statistical data in order to evaluate the indicators. The latter is composed of the report of the national accounts and the legal framework, which governs the country's taxes and their collection. Also, it is composed of the statistical reports, which are prepared constantly by the tax administrators and data of the questionnaire survey of the tax administrators and the taxpayer, etc.

In order to compare the evaluation methods of the tax system, it should be noted that the method of Gill is similar to the method, which is proposed by Tanzi. Using this method, the tax system is evaluated using the collection of indicators. However, there is more focused on the aspect of the revenue collection. It should be noted that the main disadvantages of the method of Gill are these: the relatively narrow profile system of the evaluation, the principles for the calculation of the indicators are not specified and the rating scales are not defined (see Table 1). 
Table 1. The advantages and disadvantages of the evaluation methods of the tax system, which have the similar contents

\begin{tabular}{|c|c|c|}
\hline Methodology & Advantages & Disadvantages \\
\hline $\begin{array}{l}\text { Method of } \\
\text { Tanzi }\end{array}$ & $\begin{array}{l}\text { - The aim is to fully evaluate the tax system } \\
\text { and its structure. }\end{array}$ & $\begin{array}{l}\text { - The tax system is evaluated considering only to the selected } \\
\text { expert opinion; } \\
\text { - Some indicators are criticized for their evaluation of the } \\
\text { expediency of the results; } \\
\text { - There is not defined evaluation scales; } \\
\text { - The method is not suitable for the international comparisons; } \\
\text { - The method is not normative and indicates only the most } \\
\text { important aspects of the evaluation; } \\
\text { - The generalizing indicator (or their collection), integrating the } \\
\text { partial indicator values and enabling to evaluate the overall } \\
\text { level of the tax system, is not supplied. }\end{array}$ \\
\hline $\begin{array}{l}\text { The system of } \\
\text { diagnostic } \\
\text { indicators of } \\
\text { Gill }\end{array}$ & $\begin{array}{l}\text { - For the evaluation, there is used the statistical } \\
\text { data, rather than intuitive assessments; } \\
\text { - The system can be analyzed in a systematic } \\
\text { point of view through the prism of the tax } \\
\text { revenue collection; } \\
\text { - There is taken into account the quantitative } \\
\text { and qualitative aspects of the assessment of } \\
\text { the tax system. }\end{array}$ & $\begin{array}{l}\text { - Some part of the statistical data can be hardly accessible; } \\
\text { - The narrow profile assessment; } \\
\text { - There is not defined the evaluation scales; } \\
\text { - The generalizing indicator (or their collection), integrating the } \\
\text { partial indicator values and enabling to evaluate the overall } \\
\text { level of the tax system, is not supplied. }\end{array}$ \\
\hline $\begin{array}{l}\text { The collection } \\
\text { of the } \\
\text { presentations } \\
\text { of Tanzi and } \\
\text { Pallechio }\end{array}$ & $\begin{array}{l}\text { - For the evaluation, there is used the statistical } \\
\text { data, rather than intuitive assessments; } \\
\text { - The system can be analyzed in a systematic } \\
\text { point of view through the prism of the tax } \\
\text { revenue collection; }\end{array}$ & $\begin{array}{l}\text { - There is not established a clear hierarchy of the indicators; } \\
\text { - There is not defined the evaluation scales; } \\
\text { - The generalizing indicator (or their collection), integrating the } \\
\text { partial indicator values and enabling to evaluate the overall } \\
\text { level of the tax system, is not supplied. }\end{array}$ \\
\hline
\end{tabular}

Source: compiled by the authors

The completed analysis of the tax system enables to state that the methods of the evaluation, which are presented in the scientific literature, have a tendency to focus on the individual aspects of the assessment. It should be noted that in this assessment lacks the versatility and the suggestions for the improvement of the tax system have a shortage of the validity and complexity.

The taxation is an area, where you can calculate in several ways. Unfortunately, it is often forgotten that all these calculations have to be considered with the considerable reservations. In some cases, they may provide information whether the taxes are high or low, whether their burden is raised or unbearable. The tax burden is probably mainly and the most common method, which is used in the scientific literature and in practice to evaluate the tax system. The absolute size of the tax burden is calculated as the amount, which is paid by the taxpayers, i.e., the general tax revenues of the country. According to this method, all the taxes, which are paid by the taxpayers are included in the calculation of the tax burden. However, calculating the tax burden in this method can arise some problems:

- All the taxes paid by the taxpayers cannot be reflected in one of the budgets and to calculate the general tax revenue will need more than one statistical source;

- The tax revenue of a certain fund, which was formed by the country, is accounted in the other fund of the country.

The calculation of the tax burden in absolute size allows you to compare the variation of the tax revenue over time. However, according to Conrad (1955), in order to compare the tax burden of the several countries, there must be calculated not the absolute indicators, but the relative indicators. The most commonly used indicator of the tax burden is the relation of the tax revenue and gross domestic product (GDP). The relative rate, according to the Elschner and Schwager (2005), shows, which part of the gross domestic product is redistributed through the taxes. This size can be compared not only in the one country's time scale but also internationally.

The size of the taxes, which is an average per capita, is expressed in absolute size. It is calculated as the relation of the total national budget tax revenue and population. However, the resulting size is not very useful for the 
person because this size does not evaluate the differences of the country revenue level and is not suitable for the international comparisons. The comparative method of the tax rates mostly is used to carry out the crossborder comparative analysis of the taxes when the same tax rates are compared. However, according to Atrostic and Nunn (1991), the fee is not just the rate but also it is the base. Comparing only the rates and the sizes, there is obtained very superficial information. For this reason, it is useful to compare only when the tax base is the same. In all the countries, without exception, the tax base is different, and a significant difference is visible in the base of the direct taxes. It should be noted that in this case, the most appropriate method of the evaluation of the tax system is the relative tax burden indicator. In order to carry out the comprehensive analysis of the evaluation methods, it is required to distinguish the advantages and disadvantages of the tax burden assessment methodologies (see table 2).

Table 2. The comparison of the methods of the calculation of the tax burden

\begin{tabular}{|l|l|l|}
\hline \multicolumn{1}{|c|}{ Methodology } & \multicolumn{1}{|c|}{ Advantages } & \multicolumn{1}{c|}{ Disadvantages } \\
\hline $\begin{array}{l}\text { The methodology } \\
\text { used by EUROSTAT }\end{array}$ & $\begin{array}{l}\text { All the tax revenue of the national } \\
\text { budget and of the various funds is } \\
\text { evaluated. }\end{array}$ & $\begin{array}{l}\text { - The calculated tax burden would be even more accurate if there } \\
\text { is included the various collections which are not defined by the } \\
\text { Lithuanian laws. }\end{array}$ \\
\hline $\begin{array}{l}\text { The methodologies } \\
\text { used by Lithuanian } \\
\text { Free Market Institute }\end{array}$ & $\begin{array}{l}\text { Market participants may submit the assessments, which are based on } \\
\text { their own experience and the available information; } \\
\text { In the calculation, there is included the non-tax revenue of the } \\
\text { national budget, such as the European Union's support. }\end{array}$ \\
\hline $\begin{array}{l}\text { Methodology of } \\
\text { Tax Freedom Day }\end{array}$ & $\begin{array}{l}\text { There is not included the cash costs and the time costs associated } \\
\text { with the tax administration; } \\
\text { There is not assessed the public borrowing, which can turn into a tax } \\
\text { burden in the future. }\end{array}$ \\
\hline
\end{tabular}

Source: compiled by the authors

It is necessary to carry out the detailed complex research. This research can give the possibility to calculate the actual tax burden on businesses. Also, it can help to dispel the doubts about the correct comparison of the tax burden indicator with the data, which are published by the other EU countries. In order to calculate the tax burden in Lithuania, it is advisable to use this method of the calculation: the national revenue is divided by the gross domestic product. Also, there should be involved the payments, which are depressing businesses and households and which were not approved by the Lithuanian legislation. In this case, there must be included only the tax revenue to the national budget, which is derived from the taxes, excluding revenue from the tax fines, penalties, and confiscation. Regardless of the tax administration and the arrangements of the crediting, which exists in the country, there must be included the tax revenue, which is paid to the various funds and to the other budgets. In addition, it is mandatory to include other charges, such as fees for the various licenses, registers, which are not included in one of the budgets or funds and are recognized as the revenue of the certain organizations.

The evaluation method of the classical principles of the taxation and their indicators are very rarely used in the practice. Although there are a lot of principles of the taxation and many authors present them differently, but it should be noted that in the most cases the essence is the same, but it only has the different name (see Table 3). 
Table 3. The taxation principles and their expression in the scientific literature

\begin{tabular}{|c|c|c|c|c|c|c|c|c|c|c|c|c|c|c|c|c|}
\hline The principle & 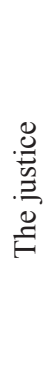 & 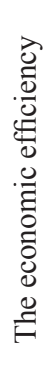 & 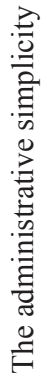 & 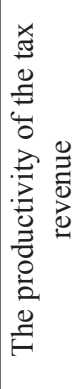 & 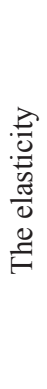 & 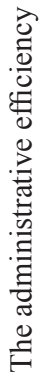 & 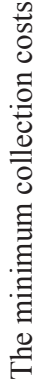 & 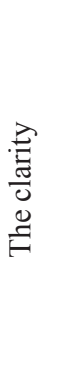 & 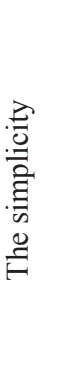 & 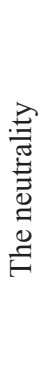 & 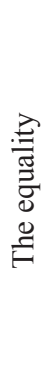 & 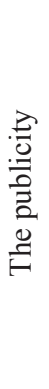 & 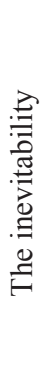 & 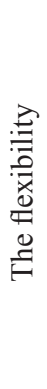 & 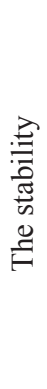 & 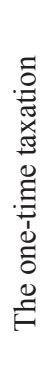 \\
\hline Smith (1937) & $\mathrm{X}$ & & & $\mathrm{X}$ & & $\mathrm{X}$ & $\mathrm{X}$ & & & & & & & & & \\
\hline Žekiene (1996) & $\mathrm{X}$ & & & & & & & $\mathrm{X}$ & $\mathrm{X}$ & & & & & & & \\
\hline Vainiene (2005) & $\mathrm{X}$ & & & & & $\mathrm{X}$ & & $\mathrm{X}$ & & $\mathrm{X}$ & $\mathrm{X}$ & $\mathrm{X}$ & & & & \\
\hline Pajuodiene (1993) & $\mathrm{X}$ & $\mathrm{X}$ & $\mathrm{X}$ & $\mathrm{X}$ & $\mathrm{X}$ & & & & & & & & & & & \\
\hline Buskeviciute (2006) & $\mathrm{X}$ & & & $\mathrm{X}$ & $X$ & & & & & & & & & & & \\
\hline LLRI (1997) & & & & & $X$ & & $\mathrm{X}$ & $\mathrm{X}$ & & & & & $\mathrm{X}$ & & & $\mathrm{X}$ \\
\hline Slemrod (1990) & & $\mathrm{X}$ & $\mathrm{X}$ & & & & & $\mathrm{X}$ & $\mathrm{X}$ & $\mathrm{X}$ & & & & & & \\
\hline European Commission (2004) & $\mathrm{X}$ & $\mathrm{X}$ & & & & & & $\mathrm{X}$ & $\mathrm{X}$ & $\mathrm{X}$ & & & $\mathrm{X}$ & $X$ & & \\
\hline ITEP (2011) & & & & & & & & $\mathrm{X}$ & $\mathrm{X}$ & $\mathrm{X}$ & $\mathrm{X}$ & & & & & \\
\hline ACCA (2009) & $\mathrm{X}$ & $\mathrm{X}$ & & $\mathrm{X}$ & $\mathrm{X}$ & $\mathrm{X}$ & & $\mathrm{X}$ & $\mathrm{X}$ & $\mathrm{X}$ & $\mathrm{X}$ & & $\mathrm{X}$ & $\mathrm{X}$ & $\mathrm{X}$ & $\mathrm{X}$ \\
\hline Kentucky Chamber (2012) & $\mathrm{X}$ & & & $\mathrm{X}$ & & & $X$ & & $\mathrm{X}$ & $\mathrm{X}$ & & & & & & \\
\hline Kaplow (2008) & $\mathrm{X}$ & & & & & $\mathrm{X}$ & $X$ & $\mathrm{X}$ & $\mathrm{X}$ & $\mathrm{X}$ & & & & & & \\
\hline
\end{tabular}

Source: compiled by the authors

In the Lithuanian and foreign scientific literature, there is presented the various possible classifications of the taxation principles, despite the differences in their wording. However, the number of the principles, which have the similar content, ranges from three to thirteen. There are six basic principles of taxation, which are highlighted by the scientists and which are mentioned in many of the scientific sources: the justice; the economic efficiency; the productivity of the tax revenue; clarity; simplicity; neutrality. It should be noted that for the tax assessment system there is not appropriate to use all the principles of the taxation. Therefore, in the further analysis of the evaluation methods of the tax system will be used only the principles, which are already selected and commonly mentioned in the scientific literature. For each principle, which is identified and selected for further analysis, there should be chosen the indicators of the evaluation. These indicators must correspond comprehensively and objectively to the basic requirements. These indicators should also comprehensively and objectively describe the features of the tax system.

It should be noted that using the classical principles of the taxation and the indicators, can be quite difficult to evaluate the tax system because the analysis of the unrelated elements does not allow objectively evaluate the entire tax system. As a result, the analysis of the tax system is limited at the international level. In addition, according to the analysis of the tax burden, the different education institutions or the different scientists offer the different indicators to assess the same tax principle. In the works of some scientists, the same indicator is proposed to evaluate the different principles of the taxation. According to Bivainis and Skackauskiene (2009), the indicator of the tax burden is proposed evaluating the tax justice and the simplicity of the tax administration. The indicator of the average tax rate is proposed evaluating the justice and the efficiency. Thus, the assessment is complicated and criticized for the selection of indicators. Also, it is complicated and criticized because of the indicators questions uncertainty (the uncertainty of the content and the measurement). 


\section{The course of the study and results}

The completed analysis of the evaluation methods of the tax system allows to state that although there is a lot of evaluation methods in practice, but neither one of them cannot be linked with the country's entrepreneurship and its promotion analysis, although the tax system has a direct impact on the entrepreneurship, its level and trends. It can also be stated that, although there is a wide variety of the assessment methods in practice, but they also have the same features, which can be called as the general tax system evaluation criteria (see Table 4).

Table 4. The expression of the tax system evaluation criteria

\begin{tabular}{|l|c|c|c|c|}
\hline \multicolumn{1}{|c|}{ Criteria, method } & $\begin{array}{c}\text { The evaluation } \\
\text { of the tax } \\
\text { administration } \\
\text { system }\end{array}$ & $\begin{array}{c}\text { The evaluation } \\
\text { of the tax } \\
\text { system } \\
\text { structure }\end{array}$ & $\begin{array}{c}\text { The evaluation of } \\
\text { the complexity } \\
\text { of the tax } \\
\text { accounting }\end{array}$ & $\begin{array}{c}\text { The evaluation } \\
\text { of the environment } \\
\text { of the tax system }\end{array}$ \\
\hline The test of the productivity of Tanzi & $\mathrm{X}$ & $\mathrm{X}$ & & $\mathrm{X}$ \\
\hline The system of the diagnostic indicators of Gill & $\mathrm{X}$ & $\mathrm{X}$ & & $\mathrm{X}$ \\
\hline The collection of the presentations of Tanzi and Pallechio & $\mathrm{X}$ & $\mathrm{X}$ & $\mathrm{X}$ \\
\hline The tax burden rate & $\mathrm{X}$ & & $\mathrm{X}$ \\
\hline The classical principles of taxation and their indicators & & & \\
\hline
\end{tabular}

Source: compiled by the authors

Based on the results of the identified tax system evaluation criteria, we can state that the biggest attention is focused on the administration of the tax system. However, the remaining evaluation criteria get an equal attention (the structure of the tax system, the environment or the accounting complexity level). Therefore, all identified evaluation criteria of the tax system are equally important and all of them must be taken into account in order to carry out a detailed analysis of the tax system. There is formed the assumption that it is appropriate to follow these criteria in order to carry out a comprehensive assessment of the tax system and in order to select the appropriate indicators which characterize them. Therefore, it is important to create a model that would be able to assess the tax system according to the specificity of the country. However, it is not appropriate to eliminate the identified evaluation methods of the tax system, which have already exist in the practice. They should be adapted and partially adapted in order to obtain the most objective and reliable results.

\section{Conclusions}

According to the systematized tax system evaluation methods, it was observed that the different evaluation methods are not able to evaluate the country's tax system comprehensively. During the method of synthesis, the disadvantages of the tax system evaluation methods were supposed and led to the development of the new method direction. Also, it helped substantiate the particularities of the tax system evaluation criteria: a) Using the advantages of the existing methods and eliminating their disadvantages; $b$ ) including the additional evaluation variables and grouping them into four groups: establishing of the operational environment, the complexity of the tax accounting and the administration of the tax system. The variables of the tax system evaluation must be selected according to these criteria: the significance and informative value; an opportunity to assess the quantitative and qualitative evaluation aspect of the tax system and its direct impact on businesses and the self-employed entrepreneurs. 


\section{References}

Abderratar, O.; Subhash, T. 1997. Macroeconomic accounting and analysis in trasition economies. Washington: International Monetary Fund Publication Services, 183. Available on the Internet: https://books.google.lt/books?id=f1sa2B913oMC\&printsec=frontcover\&hl= lt\&source $=$ gbs_ge_summary_r\&cad $=0 \# \mathrm{v}=$ onepage\&q\&f $=$ false

Alley, C.; Bentley, D. 2008. The increasing imperatyve of cross-disciplinary research in tax administration. Journal of Tax Research 6(2): 122-144. Available on the Internet: https://www.business.unsw.edu.au/research-site/publications-site/ejournaloftaxresearch-site/ Documents/paper3_v6n2.pdf

Atrostic, B.K.; Nunns, J.R. 1991. Measuring tax burden: a historical perspective, in Fifty Years of Economic Measurement: The Jubilee of the Conference on Research in Income and Wealth, Ed. by E.R. Berndt, J.E. Triplett, May 12-14, 1988, USA. University of Chicago Press, 343-420. Available on the Internet: http://www.nber.org/chapters/c5981.pdf

Atwood, T.J.; Drake, M.S.; Myers, J.N.; Myers, L.A. 2012. Home country tax system charactersitics and corporate tax avoidance: international evidence. The Accounting Review 87(6): 1831-1860. https://doi.org/10.2308/accr-50222

Bivainis, J.; Skačkauskienė, I. 2009. Kompleksinio mokesčių sistemos vertinimo rodikliu sistema [A system of indicators for the complex evaluation of tax system]. Business: theory and practice 10(4): 298-307. Available on the Internet: http://btp.press.vgtu.lt/ article/14224/

Bivainis, J., Skackauskiene, I. 2008. Mokesčių sistema Lietuvoje: vertinimass Gill metodu [Evaluation of the Lithuanian tax system in applying Gill method]. Public Administration 1(17): 43-61. Available on the Internet: http://web.a.ebscohost.com/ehost/pdfviewer/ pdfviewer?vid=1\&sid=639c5544-e392-44f6-9fda-ef07452368cd\%40sessionmgr4008

Buškevičiūtè, E. 2006. Valstybès finansai [Public finance]. Kaunas: Technologija, 441

Conrad, A.H. 1955. On the calculation of tax burdens. Economica 22 (88): 342-348. https://doi.org/10.2307/2551189

Dobrovič, J.; Gombár, M.; Benková, E. 2017. Sustainable development activities aimed at combating tax evasion in Slovakia. Journal of Security and Sustainability Issues 6(4): 761-772. https://doi.org/10.9770/jssi.2017.6.4(19)

Elschner, C.; Schwager, R. 2005. The effective tax burden on highly qualified employees. Germany: Physica-Verlag Heidelberg, 124.

European Commission. 2004. General tax principles. Working Paper of Common Consolidated Corporate Tax Base Working Group. Available on the Internet: https://ec.europa.eu/taxation_customs/sites/taxation/files/docs/body/cctbwp1finalrev1_en.pdf

Gasparėnienè, L.; Remeikienè, R.; Sadeckas, A.; Ginevičius, R. 2016. Level and sectors of digital shadow economy: the case of Lithuania. Entrepreneurship and Sustainability Issues 4(2): 183-197. https://doi.org/10.9770/jesi.2016.4.2(6)

Gill, J. 2000. A diagnostic framework for revenue administration. World Bank Technical Papers No 472, 68. Available on the Internet: http://siteresources.worldbank.org/INTTPA/Resources/DiagnosticFramework.pdf

Institute on Taxation and Economic Policy (ITEP). 2011. Tax principles: building blocks of a sound tax system. Working paper Policy Brief, 2. Available on the Internet: https://itep.org/wp-content/uploads/pb9princ.pdf

Jakštonytè, G.; Giriūnas, L. 2010. Tax system efficiency evaluation modeling with reference to V. Tanzi criteria. Economics and Management 15: 941-946. Available on the Internet: http://web.a.ebscohost.com/ehost/pdfviewer/pdfviewer?vid=0\&sid=251d53cb-0b9d4a38-880e-b06fa81611dd\%40sessionmgr4007

Kaplow, L. 2008. Optimal policy with heterogeneous preferences. NBER Working Paper Series, No. 14170. Available on the Internet: http://www.nber.org/papers/w14170.pdf

Kentucky Chamber. 2012. Tax principles. Working paper.

Lietuvos laisvosios rinkos institutas (LLRI). 1997. Proliberali mokesčių sistema - ateitis Lietuvai. Litas, 4.

Pajuodienè, G.M. 1993. Mokesčiu sistemos formavimas išsivysčiusiose šalyse. Vilnius: Lietuvos Informacijos Institutas, 36.

Profeta, P.; Scabrosetti, S. 2009. Democracy and taxation in Asian countries, in Longobardi, E., Petretto, A. (Ed). Saggi Di Economia Della Tassazione, Milano, Italy: FrancoAngeli, 181-213.

Saez, E.; Slemrod, J.; Giertz, S. H. 2012. The elasticity of taxable income with respect to marginal tax rates: A Critical Review. Journal of Economic Literature 50 (1): 3-50. Available on the Internet: http://digitalcommons.unl.edu/cgi/viewcontent.cgi?article=1053\&cont ext=econfacpub 
Sika, P.; Martišková, A. 2016. Sustainability of the pension system of the Slovak Republic in the changed socio-economic conditions. Journal of Security and Sustainability Issues 6(1): 113-123. https://doi.org/10.9770/jssi.2016.6.1(8)

Skačkauskienė, I. 2010. Tax system evaluation model, in The 6th International Conference "Business and Management 2010": Selected papers, Vol. 2. Ed. by R. Ginevičius, A. V. Rutkauskas, R. Počs, May 13-14, 2010, Vilnius, Lithuania. Vilnius: Technika, 719-727. . https://doi:10.3846/bm.2010.095

Slemrod, J. 1990. Tax principles in an international economy. World Tax Reform: Case Studines of Developed and Developing Countries, 11-25. Available on the Internet: http://pdf.usaid.gov/pdf_docs/PNABK784.pdf\#page=22

Slemrod, J. 2001. A general model of the behavioral response to taxation. International Tax and Public Finance 8(2): 119128. Available on the Internet: https://deepblue.lib.umich.edu/bitstream/handle/2027.42/46124/10797_2004_Article_325226. pdf? sequence $=1 \&$ isAllowed $=y$

Slemrod, J. 2005. The etiology of tax complexity: evidence from us state income tax systems. Public Finance Review 33(3): $279-299$. Available on the Internet: http://journals.sagepub.com/doi/pdf/10.1177/1091142105275003

Slemrod, J. 2013. Buenas notches: lines and notches in tax system design. eJournal of Tax Research 11(3): 259-283. Available on the Internet: https://www.business.unsw.edu.au/research-site/publications-site/ejournaloftaxresearch-site/Documents/eJTR_Vol11No3_2013.pdf\#page $=19$

Smith, A. 1937. The wealth of nations (1776). New York: Modern Library, 740.

Spratt, S. 2009. Development finance - debates, dogmas and new directions. Routledge, 418. Available on the Internet: https://books. google.lt/books?id=6qB8AgAAQBAJ\&printsec $=$ frontcover $\& \mathrm{hl}=1 \mathrm{t} \&$ source $=$ gbs_ge_summary_r\&cad $=0 \# \mathrm{v}=$ onepage $\& \mathrm{q} \& \mathrm{f}=$ false

Tamulevičienė, D. 2016. Methodology of complex analysis of companies' profitability. Entrepreneurship and Sustainability Issues 4(1): 53-63. https://doi.org/10.9770/jesi.2016.4.1(5)

Tanzi, V. 1977. Inflation, lags in collection, and the real value of tax revenue. Staff Papers 24(1): 154-167. Available on the Internet: http://www.jstor.org/stable/3866540?seq=1\#page_scan_tab_contents

Tanzi, V. 1983. Quantitative characteristics of the tax systems of developing countries. IMF International Monetary Fund, 31.

Tanzi, V. 2004. The IMF and tax reform. IMF Working Paper 90/39, 26. Available on the Internet: https://ssrn.com/abstract=884755

Tanzi, V. 2005. Globalization, tax system, and the architecture of the global economic system. IDB Papers, 23. Available on the Internet: http://services.iadb.org/wmsfiles/products/Publications/724426.pdf

Tanzi, V., Zee, H. H. 2000. Tax policy for developing countries. International Monetary Fund, 35. Available on the Internet: https://www. imf.org/external/pubs/ft/wp/2000/wp0035.pdf

The Association of Chartered Certified Accountants (ACCA). 2009. Tax principles: from Adam Smith to Barack Obama. Policy Paper, 12. Available on the Internet: https://www.nctbpu.org.ua/pdf/analytics/Tax_Principles.pdf

Vainienè, R. 2005. Ekonomikos terminų žodynas [Dictionary of Economic Terms], Vilnius: Tyto alba, 327.

Lukas GIRIŪNAS is the Associated Professor of Financial analysis and taxation and a Head of the International Accounting and Audit study programme at Mykolas Romeris University, Lithuania. Research interests: financial analysis, taxation, internal control and accounting.

Gintarè GIRIŪNIENĖ is the Professor of Accounting and Taxation and Director of the Institute of Finance at Mykolas Romeris University, Lithuania. Research interests: forensic and creative accounting, taxation, entrepreneurship. 